IOS Press

\title{
Control of Botrytis cinerea in strawberries with Gliocladium catenulatum vectored by bumblebees
}

\author{
Tom Van Delm ${ }^{\mathrm{a}, *}$, Sarah Van Beneden ${ }^{\mathrm{b}}$, Veerle Mommaerts ${ }^{\mathrm{b}}$, Peter Melis ${ }^{\mathrm{a}}$, Katrijn Stoffels ${ }^{\mathrm{a}}$, \\ Felix Wäckers ${ }^{\mathrm{b}}$ and Ward Baets ${ }^{\mathrm{a}}$ \\ ${ }^{a}$ Research Centre Hoogstraten, Voort 71, B-2328 Meerle, Belgium \\ ${ }^{\mathrm{b}}$ Biobest, Ilse Velden 18, B-2260 Westerlo, Belgium
}

Submitted 29 October 2014; accepted 22 December 2014

\begin{abstract}
.
BACKGROUND: Grey mould Botrytis cinerea is the most common fruit rot disease in strawberries and shelf-life is often limited because of Botrytis. Generally the disease is controlled by spraying chemical products.

OBJECTIVE: To prevent resistance and to produce strawberries with fewer residues, it is required to find alternatives. In this study, bumblebees were used as vector to transport the antagonistic fungus Gliocladium catenulatum J1446 to the flowers in order to control Botrytis.

METHODS: A trial was conducted in strawberries grown in a plastic greenhouse. Bumblebees leaving the special hive become loaded with the microbial product. The following strategies were compared: untreated control, conventional chemical spray scheme, spray application with G. catenulatum or fenhexamid, G. catenulatum (vectored). The last strategy is also tested with an additional spraying with $G$. catenulatum $(1 \mathrm{x})$ or fenhexamid $(1 \mathrm{x})$. Botrytis infection and yield were evaluated.

RESULTS: Spray applications with G. catenulatum $(3 \mathrm{x})$ or Teldor $(1 \mathrm{x})$ did not reduce the Botrytis infection in this trial. G. catenulatum vectored by bumblebees reduced grey mould, and was comparable with the conventional chemical treatment scheme. Additional sprayings with $G$. catenulatum or fenhexamid did not generate an additional reduction.

CONCLUSIONS: This greenhouse trial demonstrates that G. catenulatum vectored by bumblebees can reduce Botrytis infection and improve shelf-life of strawberries at low to moderate disease pressure. This results in a more sustainable control with healthier strawberries with fewer residues.
\end{abstract}

Keywords: Fragaria $x$ ananassa Duch., grey mould, residues, biological control

\section{Introduction}

Grey mould Botrytis cinerea is the most common fruit rot disease in strawberries and shelf-life is often limited because of Botrytis infections [1]. This problem can be reduced by cultivating strawberries under protection. However, under favourable conditions Botrytis cinerea can still cause serious losses. Infection by Botrytis cinerea occurs mainly during flowering [2], whereafter the pathogen can remain inactive for a long time and cause fruit rot pre- or post harvest $[1,3]$. Since Botrytis cinerea is mainly infecting flowers, flower protection is considered as a key management strategy to control grey mould [4].

Generally in commercial strawberry greenhouses in Belgium, the disease is controlled by spraying chemical fungicides. However, chemical fungicides can result in the fungus developing resistance [5, 6] and for a sustainable disease control and producing strawberries with fewer residues, it is required to find non-chemical alternatives.

*Corresponding author: Tom Van Delm. Tel.: +32 331570 52; Fax: +32 331500 87; E-mail: tom.vandelm@ proefcentrum.be. 
In this study, the main aim is to test whether bumblebees can be used as vector to transport an antagonistic fungus to control fruit rot in a commercial strawberry greenhouse. Kovach et al. [7] found in Geneva, New York (USA) that honeybee- or bumblebee-delivered Trichoderma harzianum is a viable option for strawberry growers to control Botrytis. Mommaerts et al. [8] proved that bumblebees can vector a microbiological control agent to reduce $B$. cinerea incidence in greenhouse strawberries. Our study investigates if this control method was comparable with common chemical treatment schemes currently used in strawberry farms in Belgium. In addition, some extra spraying treatments were included to assess whether there was an added value and which strategy resulted into the best control of Botrytis fruit rot.

\section{Material and methods}

\subsection{Field experiment}

A field trial was conducted with strawberries grown in a peat substrate under a plastic greenhouse (not heated). Tray plants of cultivar 'Elsanta' were used for an autumn crop, and planted on 10 July 2013 at 9,6 plants per square meter.

To control Botrytis, bumblebees (Bombus terrestris) were used as vector to transport the antagonistic fungus Gliocladium catenulatum J1446 (Verdera $\mathrm{B}^{4}$ ) to the flowers using the Flying Doctors ${ }^{\circledR}$ system (Biobest, Westerlo, Belgium). This system consists of a bumblebee hive with an integrated product dispenser. Bumblebees leaving the hive walk through the dispenser filled with Verdera $\mathrm{B}^{4}$ and become loaded with the microbial product (FD: Flying Doctors ${ }^{\circledR}$ with Verdera $\mathrm{B}^{4}$ ). The trial need to be split up, since the bumblebees may not be mixed over the different control strategies. Therefore, the strategies including the FD were placed in one compartment, strategies without FD in another compartment (Fig.1). The total area of the trial was $1200 \mathrm{~m}^{2}$ : a compartment of $800 \mathrm{~m}^{2}$ was treated with the FD by using four bumblebee hives, another compartment of $400 \mathrm{~m}^{2}$ was pollinated with bumblebees coming from two bumblebee hives with empty dispensers.

Within these compartments, the control strategies were placed by using four replicates of each control strategy. Each replicate consists of 60 plants $\left(6,25 \mathrm{~m}^{2}\right)$, randomized within the greenhouse correct compartment. In the two compartments, with and without the Flying Doctors system with Verdera $\mathrm{B}^{4}$, fruit yield and grading were registered each picking in four plots of 60 plants $\left(6,25 \mathrm{~m}^{2}\right)$. Fruits are graded as follows: large (diameter $\geq 35 \mathrm{~mm}$ ), small $(<35 \mathrm{~mm})$, misshapen and rotten fruits.

\subsection{Control strategies for Botrytis cinerea}

The following control strategies were compared with G. catenulatum vectored by bumblebees: untreated control, conventional chemical spray scheme, a spray application with G. catenulatum (Prestop) (3 application) or with fenhexamid (Teldor) (1 application). In addition, it was investigated whether the efficacy of G. catenulatum (vectored) could be improved by combined spraying with $G$. catenulatum (1 application) or fenhexamid (1 application).

\begin{tabular}{|c|c|}
\hline Control strategies without FD & Control strategies that include FD \\
Strategy 1: 4 replicates & \\
Strategy 2:4 replicates & Strategy 4:4 replicates \\
Strategy 3:4 replicates & Strategy 5:4 replicates \\
Strategy 7: 4 replicates & Strategy 6:4 replicates \\
\hline Compartment $1\left(400 \mathrm{~m}^{2}\right)$ & Compartment $2\left(800 \mathrm{~m}^{2}\right)$ \\
\hline
\end{tabular}

Fig. 1. Schematic overview of the trial setup. In each compartment the control strategies are placed depending whether they contain the Flying Doctors treatment or not. Each control strategy consist out of 4 replicates, randomly divided over the greenhouse compartment. 
Table 1

Different control strategies to control Botrytis cinerea in a greenhouse strawberry trial

\begin{tabular}{|c|c|c|c|c|c|}
\hline Control Strategy & $31 / 07 / 13$ & $7 / 08 / 13$ & $12 / 08 / 13$ & $30 / 08 / 13$ & 9/09/13 \\
\hline 1. Untreated control & l & l & l & l & l \\
\hline 2. Prestop $(3 x)$ & Prestop $6 \mathrm{~kg} / \mathrm{ha}$ & Prestop $6 \mathrm{~kg} / \mathrm{ha}$ & Prestop $6 \mathrm{~kg} / \mathrm{ha}$ & I & l \\
\hline 3. Teldor (1x) & Teldor $1.5 \mathrm{~kg} / \mathrm{ha}$ & 1 & I & l & l \\
\hline 4. FD Verdera $B^{4}$ & $8 \mathrm{~g} / 3-4$ days & $8 \mathrm{~g} / 3-4$ days & $8 \mathrm{~g} / 3-4$ days & $8 \mathrm{~g} / 3-4$ days & $8 \mathrm{~g} / 3-4$ days \\
\hline 5. FD Verdera $\mathrm{B}^{4}+$ & $8 \mathrm{~g} / 3-4$ days & $8 \mathrm{~g} / 3-4$ days & $8 \mathrm{~g} / 3-4$ days & $8 \mathrm{~g} / 3-4$ days & $8 \mathrm{~g} / 3-4$ days \\
\hline Prestop & Prestop $6 \mathrm{~kg} / \mathrm{ha}$ & l & I & l & / \\
\hline 6. FD Verdera $\mathrm{B}^{4}+$ & $8 \mathrm{~g} / 3-4$ days & $8 \mathrm{~g} / 3-4$ days & $8 \mathrm{~g} / 3-4$ days & $8 \mathrm{~g} / 3-4$ days & $8 \mathrm{~g} / 3-4$ days \\
\hline Teldor & Teldor $1.5 \mathrm{~kg} / \mathrm{ha}$ & 1 & I & I & I \\
\hline 7. Chemical control & Frupica $0.6 \mathrm{~kg} / \mathrm{ha}$ & Frupica $0.6 \mathrm{~kg} / \mathrm{ha}$ & Teldor $1.5 \mathrm{~kg} / \mathrm{ha}$ & Teldor $1.5 \mathrm{~kg} / \mathrm{ha}$ & Signum $1 \mathrm{~kg} / \mathrm{ha}$ \\
\hline
\end{tabular}

The treatments were applied as shown in Table 1. Spraying with G. catenulatum was performed on 31 July, 7 August and 12 August at $6 \mathrm{~kg} / \mathrm{ha}$. Fenhexamid was sprayed once on $31 \mathrm{July}$ at $1.5 \mathrm{~kg} / \mathrm{ha}$. The dispensers in the hives of FD-compartment were filled with $8 \mathrm{~g}$ Verdera $\mathrm{B}^{4}$ every three to four days (twice a week). There were four bumblebee hives filled with VerderaB ${ }^{4}$ in the compartment of $800 \mathrm{~m}^{2}$. Inside this compartment, four plots were treated by spraying G. catenulatum ( $6 \mathrm{~kg} / \mathrm{ha})$ and four plots with fenhexamid $(1.5 \mathrm{~kg} / \mathrm{ha})$, both on $31 \mathrm{July} 2013$. The chemical control object was treated with mepanipyrim (Frupica; $0.6 \mathrm{~kg} / \mathrm{ha}$ ) on $31 \mathrm{July}$ and 7 August, with fenhexamid (Teldor; $1.5 \mathrm{~kg} / \mathrm{ha}$ ) on 12 and 30 August and with boscalid+pyraclostrobin (Signum; $1 \mathrm{~kg} / \mathrm{ha}$ ) on 9 September 2013.

For controlling other pests and diseases, it is important to pay attention to the use of crop protection products. These products should be compatible with $G$. catenulatum and with bumblebees. It is possible to lock bumblebees during and after treatment, but if this occurs no Verdera $\mathrm{B}^{4}$ can be distributed by the bumblebees. Products were selected to minimize the need for locking bumblebees as much as possible.

\subsection{Botrytis inoculation and natural infection}

Artificial inoculation with the pathogen Botrytis cinerea (isolate PCF232) was performed during flowering to test efficacy under higher (artificial) disease pressure. Spore suspension was used for inoculation at a concentration of $2 * 10^{5}$ spores $/ \mathrm{mL}$ with $1 / 4$ PDB (Potato Dextrose Broth). For each replicate, 50 open flowers were labelled and inoculated with $20 \mu \mathrm{L} \mathrm{B}$. cinerea suspension per flower of the at 31 July and 7 August. On 13 August 25 flowers were labelled and inoculated. After inoculation the plants were covered with plastic for $24 \mathrm{~h}$ to ensure an elevated relative humidity.

Pre- and post harvest Botrytis infection were evaluated. At each harvest date, all ripe labelled fruits were picked. At five different dates 25 unlabeled fruits per plot were picked. Infested fruits were scored and discarded immediately while healthy fruits were stored at $4^{\circ} \mathrm{C}$ in separate closed plastic boxes with a moist filter paper. The presence of $B$. cinerea was scored 14 days after harvest. The strawberries with mycelium growth, were then selected and placed at $20^{\circ} \mathrm{C}$ for 2 days. This stimulated spore production and facilitated identification.

\section{Results}

\subsection{Yield and grading}

Harvest was between 12 August and 9 October 2013, divided over 15 pickings, with midharvest (50\% of total production harvested) between 30 August and 1 September 2013. The yield in the FD compartment was $3,05 \mathrm{~kg} / \mathrm{m}^{2}$ ( $320 \mathrm{~g} / \mathrm{plant})$. There was no statistically significant difference with the control treatment $\left(3,28 \mathrm{~kg} / \mathrm{m}^{2} \mathrm{or} 340 \mathrm{~g} / \mathrm{plant}\right)$. The grading he grading was also not significant and similar for the two treatments: approximately 56-60\% large fruits, $38-42 \%$ small fruits and 1-2\% misshapen fruits. Also here the small differences are negligible. 


\subsection{Botrytis assessments}

Natural disease pressure. Of the five different picking dates, the occurrence of grey mould after cold storage did not differ statistically on 2/09 and 5/09 (Table 2). On 21/08, 26/08 and 16/09 there were statistically significant differences with the untreated control: the chemical control resulted in less fruits rotten on 26/08 and 16/09, FD showed a lower Botrytis infection on 26/08, and on 21/08 FD in combination with Teldor resulted in less fruits rotten. All data averaged showed for the untreated control 53.5\% of fruit rotten after cold storage. For the sprayed objects with Prestop (strategy 2) and Teldor (strategy 3), the infection percentage was similar: 52.0 and 47.8, respectively. The chemical control showed a statistical lower infection with $40.3 \%$ fruits rotten. The FD treatment (strategy 4 ) resulted in $36.6 \%$ of rotten fruit, which is similar to the chemical strategy reference result, representing a statistically significant reduction in Botrytis infection compared to the untreated control. The strategies with FD in combination with Prestop or Teldor gave infection percentages of $41.5 \%$ and $39.2 \%$, respectively, but were not significantly different to the other treatments.

Inoculated fruits. At seven different dates all ripe labelled fruits were picked. In total eight fruits were rotten at harvest. The first and second inoculation (on 31/07 and 7/08) showed significant differences between treatments, and with FD showing the lowest infection rate. The third inoculation did not result in statistical differences.

When all data of the three inoculations were averaged, the untreated control showed $63.1 \%$ of fruit rotten after the cold storage. The Prestop spray treatment (strategy 2) showed $66.0 \%$ of fruit rotten, with Teldor (strategy 3 ) showing a similar result with $63.3 \%$ of fruit rotted. All strategies with FD (strategy 4-5-6) gave lower percentages of rotten fruit, from 45,9 to $53,4 \%$. The chemical control strategy (strategy 7 ) resulted in 55,7\% of fruit rotten, while only strategy 6 (FD with 1 spray of Teldor) was significantly better compared to the untreated control, with 45,9\% of fruit rotten (Table 3 ).

Table 2

Infection rates (\%) on strawberry fruit after 14 days in cold storage at $4{ }^{\circ} \mathrm{C}$ under natural disease pressure

\begin{tabular}{|c|c|c|c|c|c|c|c|c|c|c|c|c|}
\hline \multirow{2}{*}{$\frac{\text { Control strategy }}{1 . \text { Untreated control }}$} & \multicolumn{2}{|c|}{$21 / 08 / 13$} & \multicolumn{2}{|c|}{$26 / 08 / 13$} & \multicolumn{2}{|c|}{$2 / 09 / 13$} & \multicolumn{2}{|c|}{$5 / 09 / 13$} & \multicolumn{2}{|c|}{$16 / 09 / 13$} & \multicolumn{2}{|c|}{ All data } \\
\hline & 58.0 & a & 54.0 & a & 62.0 & ns & 40.0 & ns & 58.7 & $a b$ & 53.5 & a \\
\hline 2. Prestop $(3 x)$ & 50.0 & $a b$ & 47.0 & $\mathrm{ab}$ & 76.0 & ns & 35.0 & ns & 54.0 & $a b$ & 52.0 & $\mathrm{ab}$ \\
\hline 3. Teldor $(1 \mathrm{x})$ & 44.0 & $a b$ & 54.0 & a & 64.0 & ns & 29.0 & ns & 56.0 & $a b$ & 47.8 & $\mathrm{ab}$ \\
\hline 4. FD Verdera $B^{4}$ & 37.0 & $\mathrm{ab}$ & 27.0 & $\mathrm{~b}$ & 53.0 & ns & 28.0 & $\mathrm{~ns}$ & 45.0 & $a b$ & 36.3 & $\mathrm{~b}$ \\
\hline 5. FD Verdera $B^{4}+$ Prestop & 41.0 & $\mathrm{ab}$ & 32.0 & $a b$ & 55.0 & ns & 38.0 & ns & 49.0 & $\mathrm{ab}$ & 41.5 & $\mathrm{ab}$ \\
\hline 6. FD Verdera $\mathrm{B}^{4}+$ Teldor & 27.0 & $\mathrm{~b}$ & 36.0 & $a b$ & 55.0 & ns & 38.7 & ns & 66.0 & a & 39.2 & $\mathrm{ab}$ \\
\hline 7. Chemical control & 35.0 & $\mathrm{ab}$ & 26.0 & $\mathrm{~b}$ & 66.0 & Ns & 34.0 & ns & 38.0 & $\mathrm{~b}$ & 40.3 & $\mathrm{~b}$ \\
\hline
\end{tabular}

Significance $p<0.05$ according to Duncan.

Table 3

Infection rates $(\%)$ on strawberry fruit after inoculation with $\mathrm{B}$. cinerea followed by 14 days in cold storage at $4{ }^{\circ} \mathrm{C}$.

\begin{tabular}{|c|c|c|c|c|c|c|c|c|}
\hline \multirow{2}{*}{$\begin{array}{l}\text { Control strategy } \\
\text { 1. Untreated control }\end{array}$} & \multicolumn{2}{|c|}{$\begin{array}{c}\text { Inoculation } \\
31 / 07 / 13\end{array}$} & \multicolumn{2}{|c|}{$\begin{array}{c}\text { Inoculation } \\
7 / 08 / 13\end{array}$} & \multicolumn{2}{|c|}{$\begin{array}{c}\text { Inoculation } \\
13 / 08 / 13\end{array}$} & \multicolumn{2}{|c|}{ All data } \\
\hline & 65.6 & $a b$ & 68.9 & $a b$ & 54.9 & ns & 63.1 & a \\
\hline 2. Prestop (3x) & 73.8 & $\mathrm{a}$ & 75.4 & $a b$ & 48.8 & ns & 66.0 & $\mathrm{a}$ \\
\hline 3. Teldor (1x) & 47.6 & $a b$ & 76.9 & $\mathrm{a}$ & 65.4 & ns & 63.3 & a \\
\hline 4. FD Verdera $B^{4}$ & 38.4 & $\mathrm{~b}$ & 57.1 & $\mathrm{~b}$ & 51.0 & ns & 48.9 & $\mathrm{ab}$ \\
\hline 5. FD Verdera $B^{4}+$ Prestop & 45.2 & $\mathrm{ab}$ & 57.3 & $\mathrm{~b}$ & 57.8 & ns & 53.4 & $\mathrm{ab}$ \\
\hline 6. FD Verdera $\mathrm{B}^{4}+$ Teldor & 33.7 & $\mathrm{~b}$ & 64.9 & $a b$ & 39.0 & ns & 45.9 & $\mathrm{~b}$ \\
\hline 7. Chemical control & 44.0 & $a b$ & 69.0 & $a b$ & 54.2 & ns & 55.7 & $\mathrm{ab}$ \\
\hline
\end{tabular}

Significance $p<0.05$ according to Duncan. 


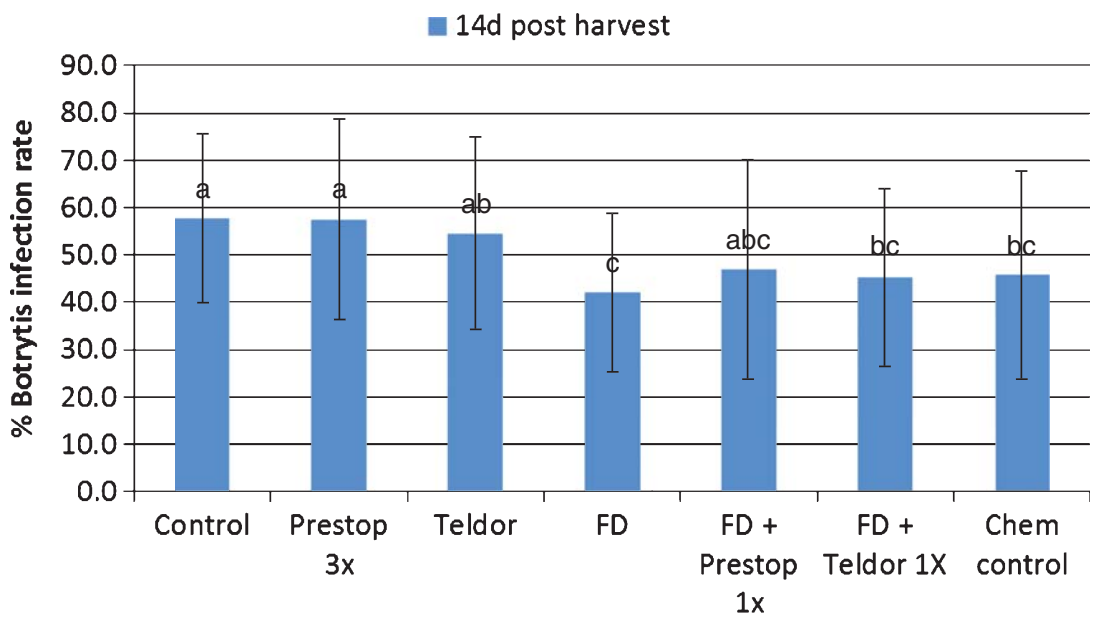

Fig. 2. Botrytis-infection rates (\%) for all fruits assessed 14 days post harvest (significance $p<0.05$ Duncan).

\subsection{General efficacy}

To obtain a general efficacy of the trial, all data of inoculated and non-inoculated fruits, were averaged (Fig. 2). The untreated control showed $57.7 \%$ of fruit rotten after cold storage. Three spray applications with G. catenulatum $(57.5 \%)$ or 1 spray application with Teldor (54.6\%) did not reduce the Botrytis infection. The conventional chemical treatment scheme caused a significant reduction of grey mould and resulted in $45.8 \%$ infection after cold storage. Also the FD strategy (strategy 4) showed a significant lower infection rate of $42.1 \%$, which was comparable to the conventional chemical control strategy (strategy 7). The additional sprayings with Prestop or Teldor did not generate an additional reduction in infectation compared to the FD strategy with 46.9 and $45.2 \%$ infection rates, respectively.

\section{Discussion}

The dispenser with Verdera $\mathrm{B}^{4}$ used in the Flying Doctors ${ }^{\circledR}$ System resulted in good fruit set and yield. Grading of fruit was similar for treated and untreated flowers. So there was no negative effect on the bumblebees nor on pollination. This is in accordance with the findings of Kovach et al. [7], who found no negative effects on bees loaded with T. harzianum, and those of Mommaerts et al. [8] who showed no negative effects on bumblebee foraging activity or working bumblebees survival.

*** Under natural disease pressure and after inoculation of flowers, lower percentages of rotten fruit due to Botrytis infection were found in most of the FD strategies and the conventional chemical control strategy compared to the untreated control, although not all these results were statistically significant. In general, disease pressure was moderately low in this trial, with the untreated control resulting in 53.5\% rotten fruit after two weeks of storage. This is probably due to weather conditions during flowering, the main period for pre-harvest infections of $B$. cinerea [2]. During this period there were very high temperatures (during daytime $>25^{\circ} \mathrm{C}$ ) with low relative humidity (during daytime $<50-60 \%$ ) in the greenhouse (data not shown). Maas [1] described favourable temperatures for Botrytis spore production between $15-22^{\circ} \mathrm{C}$ at high relative humidity or leaf wetness. Artificial inoculation could increase the infection rate to $63.1 \%$, but it is still quite low for inoculated flowers. These relatively low percentages of rotten fruits after 14 days of cold storage made it difficult to obtain consistent significant differences between different control strategies. The variation between the replicates within one control strategy is relatively high, so under these conditions with low to moderate Botrytis-pressure, probably more fruits should have been assessed to find statistically more significant differences.

Nevertheless, when all assessed fruits - inoculated and non-inoculated - were evaluated, the number of fruits per plot increased. This trial showed that use of $G$. catenulatum vectored by bumblebees was able to reduce the 
Botrytis infection in a commercial strawberry greenhouse. At low/moderate disease pressure as in this trial, the infection rate was comparable to a conventional chemical control strategy. This is in agreement with other trials conducted in different locations with several microbiological control agents. Most of these also showed a reduced infection of Botrytis. Wei $\beta$ et al. [9] tested the yeast Aureobasidium pullullans dispersed by bumblebees in protected strawberry cultivation, and also obtained reduced Botrytis cinerea infection. Kovach et al. [7] also found that vectoring a microbiological control (Trichoderma harzianum) reduced the number of Botrytis cinerea infected strawberries to the same level as the control with spraying chemical fungicides. Also Shafir et al. [10] showed in Israel that it was possible to suppress Botrytis cinerea - at a low to medium disease pressure - in strawberry fields with Trichoderma harzianum T39 vectored by bumblebees, and this control was better than in the chemical treatment. In this Israeli trial, non of the treatments controlled Botrytis well at a high disease pressure. Mommaerts et al. [8] investigated the effect of $G$. catenulatum vectored by bumblebees, and showed that under a high disease pressure, the system could significantly increase the percentage of pre- and postharvest non-infected fruits. Due to weather conditions in our trial, we could not test the efficacy at high disease pressure. That might have been a reason that the additional sprays with Prestop or Teldor to the FD could not improve the results. At higher disease pressure, these additional spray treatments might have improved the results. This should be further investigated to find a complete strategy to make it possible at high disease pressure to control Botrytis cinerea with G. catenulatum vectored by bumblebees in strawberry greenhouses. This could extend shelf-life of greenhouse grown strawberries and a more sustainable control with healthier strawberries due to fewer residues can be achieved.

\section{References}

[1] Maas JL. Compendium of Strawberry Diseases. 2nd ed. St. Paul USA: APS Press; 1998.

[2] Bristow PR, McNicol RJ, Williamson B. Infection of strawberry flowers by Botrytis cinerea and its relevance to grey mould development. Ann. of Appl. Biol. 1986; 109:545-554.

[3] Powelson EL. Initiation of Strawberry fruit rot caused by Botrytis cinerea. Phytopathol. 1960; 50(7): $491-494$.

[4] Mertely JC, MacKenzie SJ, Legard DE. Timing of fungicide applications for Botrytis cinerea based on development stage of strawberry flowers and fruit. Plant disease 2002; 86(9): 1019-1024.

[5] Weber RWS. Resistance of Botrytis cinerea to multiple fungicides in northern German small-fruit production. Plant Disease 2011; 95: 1263-1269.

[6] Leroch M, Plesken C, Weber RWS, Kauff F, Scalliet G, Hahn M. Gray Mold Populations in German Strawberry Fields Are Resistant to Multiple Fungicides and Dominated by a Novel Clade Closely Related to Botrytis cinerea. Appl. Environ. Microbiol. $2014 ; 79(1)$ : $159-167$.

[7] Kovach J, Petzoldt R, Harman GE. Use of Honey Bees and Bumble Bees to Disseminate Trichoderma harzianum 1295-22 to Strawberries for Botrytis Control. Biol. Control 2000; 18(3): 235-242.

[8] Mommaerts V, Put K, Smagghe G. Bombus terrestris as pollinator-and-vector to suppress Botrytis cinerea in greenhouse strawberry. Pest Manag. Sci. 2011; 67(9): 1069-1075.

[9] Weiß A, Weißhaus S, Hinze M, Leistra P, Kunz S. Dispersal of Aureobasidium pullulans by pollinating insects to control Botrytis infection in strawberries. In: roceedings of the 15th International Conference on Organic Fruit-Growing. FöKO e. V., Weinsberg. 2012. p. $228-234$.

[10] Shafir S, Dag A, Bilu A, Abu-Toamy M, Elad Y. Honey bee dispersal of the biocontrol agent Trichoderma harzianum T39: effectiveness in suppressing Botrytis cinerea on strawberry under field conditions. Eur. J. Plant Pathol. 2006; 116:119-128. 